\title{
RADIOCARBON DATES FROM THE JEWISH CATACOMBS OF ROME
}

\author{
Leonard V Rutgers \\ Faculty of Theology, Utrecht University, POB 80105, 3508 TC Utrecht, The Netherlands. Email: lrutgers@ theo.uu.nl. \\ Arie F M De Jong • Klaas van der Borg \\ Faculty of Physics and Astronomy, Utrecht University, POB 80000, 3508 TA Utrecht, The Netherlands
}

\begin{abstract}
This paper reports on the first chronological assessment of the Jewish Catacombs of the ancient Rome performed by accelerator mass spectrometry (AMS) dating of small-size charcoal fragments scattered in the mortar used for sealing off the graves in the Villa Torlonia Catacomb complex. The significance of the obtained ${ }^{14} \mathrm{C}$ readings has been carefully evaluated by taking into consideration the known technologies of quicklime production during Roman and recent times. The new data are of great concern for providing evidence that the Jewish catacombs were used for burial since the first century AD, thus some two centuries prior to the period traditionally believed to be the starting point of burial in the Jewish catacombs of ancient Rome. Such a significant aging of the Jewish catacombs could result in a deep re-examination of the current understanding of the beginning and the evolution of the custom of catacomb burial in both Jewish and early Christian communities in Rome.
\end{abstract}

\section{INTRODUCTION}

The dating of the Jewish catacombs of ancient Rome has been a controversial issue for 400 years (Rutgers 1995) and even today has not yet been accomplished satisfactorily due to several interconnected constraints. Difficulties arise because neither materials suitable for isotope dating nor archaeological findings with impressed age (e.g. coins and/or dated inscriptions) were so far uncovered in the Jewish catacombs. Archaeological analysis has shown that the 255 identified and dated brick and tile stamps represent reused artifacts. Therefore, they can only provide us with a terminus post quem (Rutgers 1998).

So far, any attempt of dating the Jewish catacombs of Rome relied on the standard archaeological method of relative chronology, viz., typological comparison of the findings from the catacombs with those from other archaeological contexts, that is the same approach also applied in studying the analogous Christian underground monuments in Rome (Deckers 1992; Guyon 1994). The results of such a relative dating, however, are highly problematic inasmuch as they depend on the tentative assumption that evolution patterns and stylistic traits did develop coherently and continuously through a sequence of well recognizable steps (Borbein 2000). The above mentioned assumption, however, has to be rejected, particularly in the case of late antique wall paintings (Fèvrier 1989).

A reliable dating of the Jewish catacombs is also severely hampered because the archaeological findings are not uncovered in significant, well-sealed stratigraphic sequences (Rutgers 2000). As a rule, the considered archaeological features are located in subterranean galleries, subjected to continuous frequentation over some centuries and frequently, as indicated by damaged graves, pillaged by robbers for both valuables and building materials. Later on, late antique and early medieval lime burners in search of raw materials conceivably joined the ranks of the previous grave robbers (Codex Theodosianus 9.17.2 of 349 AD), as did subsequent visitors (Lanciani 1967; Osborne 1985). In more recent times, the dilapidation of the catacombs resulting from neglect and crude research methods by pre-modern scholars destroyed or at least overshadowed the original archaeological context of many archaeological and epigraphic features.

In an attempt to break the deadlock resulting from earlier studies and research methodologies and to circumvent the constraints posed by subsequent disturbances of the archaeological record, a survey was carried out in the Villa Torlonia catacomb complex in 1997 in the framework of a dedicated 
project. The monument was selected for representing an ideal case study suitable to afford insight into the intriguing matter of dating the Jewish catacombs of Rome. It is the largest still surviving Jewish catacomb in Rome and since its discovery in 1919 has been the subject of various investigations, including a thorough archaeological campaign in the years 1973-1974 (Fasola 1976). Previous accounts on the catacomb complex, used by Jews exclusively, provided evidence that it consists of two catacombs lying at different depth, interconnected subsequently, possibly because of a collapse in area C1/E1 (Figure 1). Despite all this previous research, however, the important task of dating the catacombs was not accomplished adequately. Scholars just assigned the Jewish Villa Torlonia complex to the third/fourth centuries $\mathrm{AD}$, thus roughly contemporary to the Christian catacombs of Rome. However, such a chronological assignment was not based on sound evidence.

We aim here to establish the age of the Jewish catacombs in Rome by means of AMS ${ }^{14} \mathrm{C}$ dating of small charred vegetal remnants isolated from the mortar used to seal the graves. Although charcoal enclosed in mortar has been successfully used to run ${ }^{14} \mathrm{C}$ dating of Medieval buildings in Ireland (Berger 1992), so far the method was neither applied to Jewish nor Christian catacombs.

\section{METHOD AND DESCRIPTIVE BACKGROUND}

Most of the graves in the Villa Torlonia catacombs are of the loculus type, that is simple, rectangularly shaped, aligned along both walls of the subterranean galleries, averaging 180 and $50 \mathrm{~cm}$ in length and depth, respectively and ranging between 40 and $60 \mathrm{~cm}$ in height. The graves were sealed according to the following three distinct techniques, by using: 1) stone plaques, 2) (reused) tiles placed contiguously and vertically, and 3) small walls made up of bricks and rubble covered by a smooth layer of whitish, fine mortar suitable for painting the observed red colored funerary inscriptions (Figure 2). A careful inspection revealed some rare small bits of charcoal encased into the mortar plastered onto the latter variety of grave closure. For being scarce and randomly distributed only in a limited number of graves, it appears that these charcoal occurrences are merely occasional rather than resulting from systematic additions in the course of mortar preparation. It is likely that the charcoal bits derive from the firing of the limekiln and, far subordinately, while slackening the quicklime and mixing it up with the mineral aggregate needed to prepare the mortar.

From the mortar on the surface of five distinct graves distributed in both catacombs of the complex, single charcoal fragments were collected and submitted to ${ }^{14} \mathrm{C}$ dating. Their identifiers (Table 1) provide the location on the catacombs map (Figure 1): as an example the charcoal labeled "B4-E7-1" comes from gallery B4, seventh row of graves along the Eastern gallery wall, first loculus from the bottom.

The graphite targets, analyzed at the Utrecht AMS facility (van der Borg et al. 1997), were prepared with the $\mathrm{CO}_{2}$ obtained by burning the charcoal samples previously submitted to the acid-alkali-acid chemical pretreatment. The carbon weight yielded by the samples was some $2 \mathrm{mg}$ with the exception of sample C2-S1-III, which lower carbon content $(0.7 \mathrm{mg})$ resulted in a relatively higher analytical uncertainty.

\section{RESULTS AND DISCUSSION}

Table 1 lists the results of radiocarbon dating for the five analyzed samples. The reported calibrated ages $( \pm 1 \sigma)$ were calculated with the computer program Calib 4.3 (Stuiver and Reimer 1993). Four out of five ages range from 1983 to $1735 \mathrm{BP}$, thus bracketing the calibrated time span BC 40-AD 340. By contrast, the age of sample UtC-6719 (2144 \pm 46 BP, which calibrates to BC 349-94) is obviously too old to be consistent with the framework of the studied archaeological site and it can be accounted for only by invoking a serious "old wood" effect. 


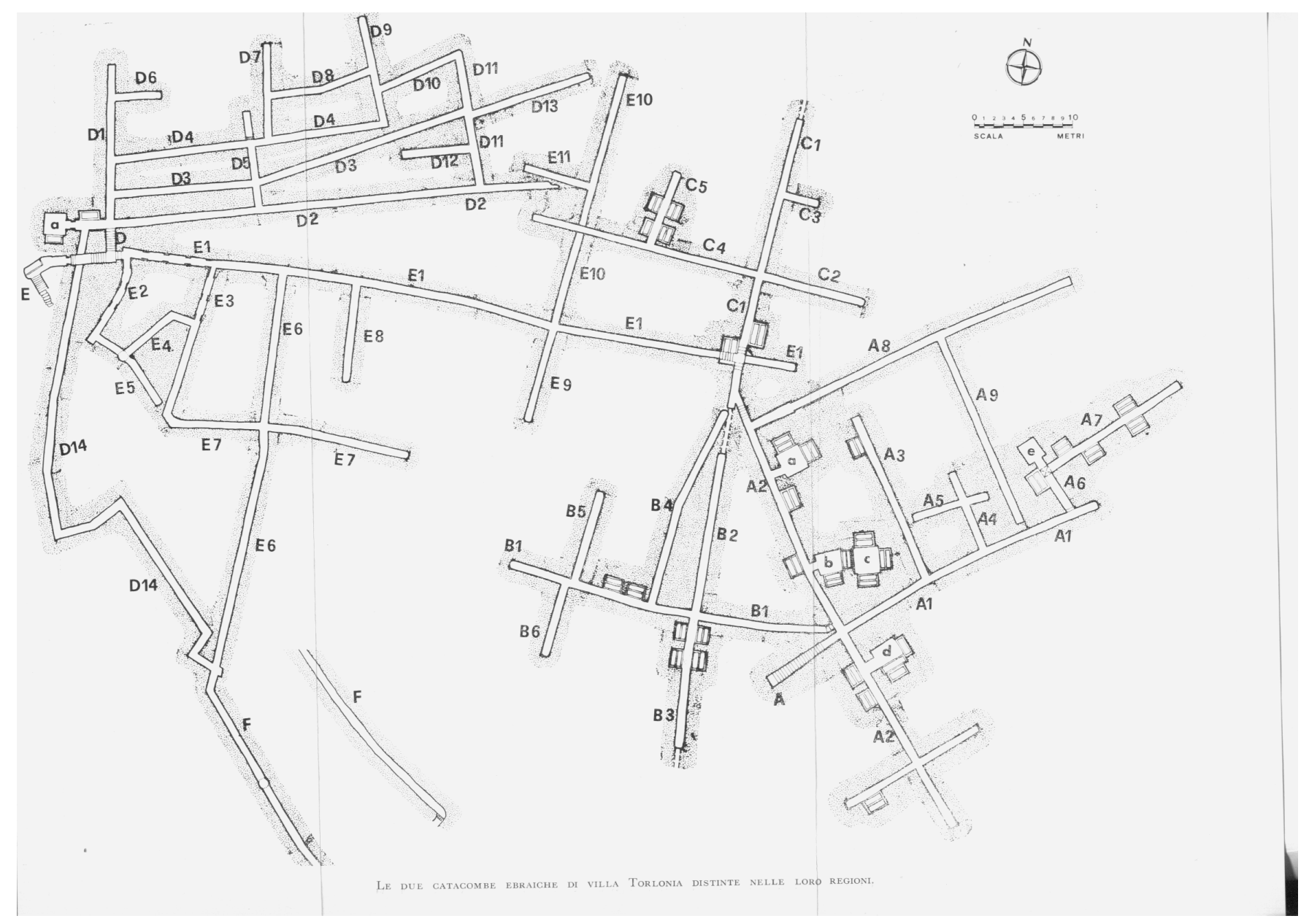




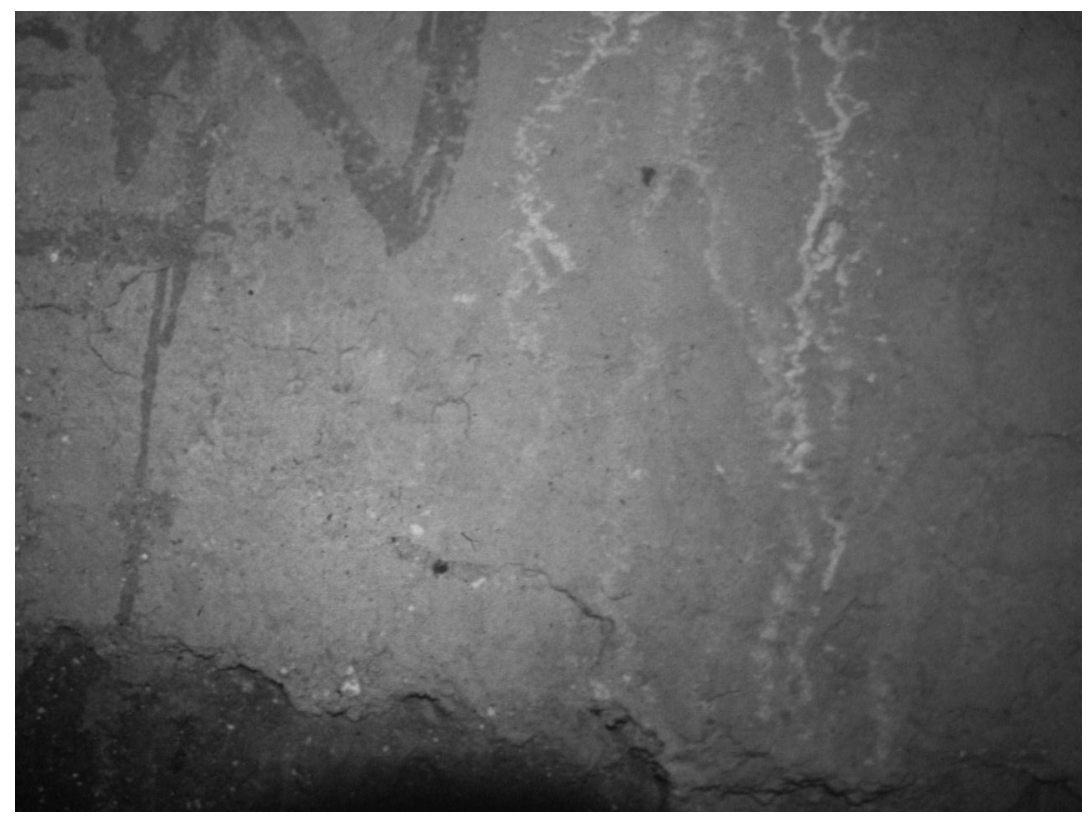

Figure 2 Loculus closure in the Villa Torlonia Catacomb, consisting of a tuff blocks kept in place with mortar. Its exposed surface, plastered by a thin, smooth, whitish layer of fine mortar, shows remnants of a red colored funerary inscription.

Table 1 Data from catacomb charcoal fragments

\begin{tabular}{|c|c|c|c|c|}
\hline Sample identifier & $\begin{array}{l}\delta^{13} \mathrm{C} \\
(\% \circ)\end{array}$ & $\begin{array}{l}\text { Age } \\
(\mathrm{BP})\end{array}$ & $\begin{array}{l}\text { Lab code } \\
\text { (UtC-) }\end{array}$ & $1 \sigma$-calendar age ${ }^{\mathrm{a}}(\mathrm{yr})$ \\
\hline B4-E7-1 & -24.6 & $1753 \pm 33$ & 6718 & cal AD 241-263, 274-339 \\
\hline C2-S1-III & -25.2 & $2144 \pm 46$ & 6719 & cal BC 349-318, 228-221, 206-94 \\
\hline Entrance-E1-ceiling & -25.4 & $1983 \pm 33$ & 6720 & cal BC 37-32, 20-12, 0-34 cal AD, 36-60 \\
\hline D10-N1-II & -25.2 & $1831 \pm 30$ & 6721 & cal AD 133-163, 168-204, 204-223 \\
\hline D14-E11-II & -25.2 & $1915 \pm 29$ & 6722 & cal AD 66-94, 96-127 \\
\hline
\end{tabular}

${ }^{a}$ Calibrated with the program Calib, version 4.3 (Stuiver and Reimer 1993).

The results of the present investigation are of great concern in that the obtained consistent set of ${ }^{14} \mathrm{C}$ dates urges us to reconsider the current chronological assignment of the Villa Torlonia Jewish catacombs and, consequently, some notable historical assumptions. However, prior to drawing any archaeological/historical conclusion we need to evaluate the reliability of the new dates by discussing to what extent the two events we associate-viz., the origin of the dated charcoal samples and the sealing of the graves-could have been actually coeval.

It has been previously noted that the inclusions of charcoal bits in the mortar were rare, randomly distributed, and that they occurred only accidentally. Most likely, they derive from the process of firing the carbonate rocks to prepare quicklime. In ancient Rome the huge need for quicklime and its hydrated lime derivative (Lanciani 1975, Lega 1999) was mostly satisfied by professional lime burners with dedicated, technologically evolved plants (limekilns) comparable, for example, to those reported from the sites of Iversheim (Sölter 1970), Vuippens (Spycher et al. 1981), Weekley (Jackson 1973), and Sagalassos (Poblome 2000). However, quicklime in subordinate amounts was also occasionally obtained on-site with the less sophisticated "mixed layers pit" technique (Michalowski 
1962; Dix 1982; Uscatescu and Martín-Bueno 1997; Lavergne and Suméra 2000)—a simple, inexpensive method to prepare home-made quicklime was still popular at the beginning of the last century throughout most of the Italian countryside. According to the demographic evidence for the studied Jewish catacombs (Rutgers, forthcoming) less than two dozen graves per year were sealed, only in part with mortar: therefore such mortar could have been easily provided by a quick, smallscale preparation on-site. Still, it cannot be ruled out that the mortar was made with professionally fired and slacked quicklime, since a community of the Roman Jews was named after its economic activity, "Calcarenses," which is the Latin term for the people dealing with mortar, its ingredients, preparation, etc. (Noy 1995, nos. 69, 98, 165, 558, and 584; Lega 1999).

By accepting that, independently from the firing technique, the dated bits of charcoal strictly record the quicklime production, a proper evaluation of the ${ }^{14} \mathrm{C}$ readings compels us to consider the characteristics of the wood used as a fuel. According to the first account in the Historia Plantarum (5.9.4) of Theophrastus (372-287 BC), limekilns were customarily fired with brushwood, since this allows one to attain the high temperature required for calcination faster than does large size wood. Archaeological data support such a practice: as an example only charred twigs and branches less than $4 \mathrm{~cm}$ in diameter were uncovered in the limekilns excavated at Weekley (Jackson 1973). Further, even today, traditionally operated limekilns are fired with short-lived vegetal matter. Being unsuitable for long storage, such matter is collected shortly before of firing. The most common fuels are thistles and weeds (Canaan 1932; Dalman 1942), and pine cones and olive kernels (Adam 1994), along with a variety of vegetal trimmings (DeLaine 1997).

Based on the above evidence concerning the production of quicklime and assuming that four out of five dated charcoal fragments from the Villa Torlonia catacombs originated from short-lived vegetation, we can argue that the measured ${ }^{14} \mathrm{C}$ dates are reasonably unaffected by "old wood" biases and therefore are a clue for establishing the sealing time of the graves.

In this respect let us stress that the ${ }^{14} \mathrm{C}$ readings are of great concern in that they point out that the Villa Torlonia Catacomb complex was in use since the first century AD instead of the so far popularly supposed third/fourth centuries AD. At first glance, the difference in the aging of the Jewish catacomb complex (some two centuries) could appear quite striking. However, the found shift in age can be reasonably accounted for by the fact that all previous chronological inferences relied on methods plagued by several constraints. In addition, it should be pointed out that the new dating herein proposed is in fair agreement with the overall historical framework, as according to ancient literary sources a permanent Jewish settlement in Rome appeared in the course of the first century BC (Solin 1983). Given that the only Jewish graves known in Rome are those in the Jewish catacombs - that is burial sites traditionally dated to the end of the second and early third century AD at the earliest—scholars have long wondered where the Jews buried their dead prior to the usage of such catacombs. The results of ${ }^{14} \mathrm{C}$ dating herein reported are valuable for solving the above puzzling question in that they point out that the Jews in ancient Rome neither had burial places other than catacombs (Noy 1998) nor their graves disappeared: they were just buried in the catacombs starting in the first century AD.

\section{CONCLUSION}

AMS dating of charcoal fragments enclosed in mortar revealed a powerful tool for achieving a sound chronological assessment of the Jewish Catacombs in Rome. The new data herein reported strongly suggest that the traditional dating of the Jewish catacombs at Villa Torlonia needs a careful and comprehensive re-evaluation. If the new ${ }^{14} \mathrm{C}$ chronology of the Villa Torlonia Jewish catacombs 
will be confirmed by further investigations, it will exert a dramatic impact on our overall knowledge on the relationship between Jewish and Christian catacombs, particularly concerning Jewish influence on early Christian burial customs in Rome. In addition, as a valuable by-product, the new data are a further warning on the limited effectiveness of relative chronology based on tools such as typology of artifacts and/or paleographic features of inscriptions when applied to particular archaeological contexts.

\section{ACKNOWLEDGMENTS}

For permission to study the Villa Torlonia materials, thanks are due to the Soprintendenza Archeologica di Roma. Organizational support was provided by the Istituto Olandese, the American Academy, the Union of Italian Jewish Communities-in particular its former president, Mrs T Zevi-the Rabbinate of Rome, the Commissione Bilaterale Ministero per i Beni Culturali and the the Deutsches Archäologisches Institut, Abteilung Madrid. Financial support was provided by the Kress Foundation and by several anonymous donors. For their unstinting support during the project, special thanks are due to Mariarosaria Barbera and Eric M Meyers. We would finally also like to thank the anonymous reviewers of our manuscript.

\section{REFERENCES}

Adam J-P. 1994. Roman building: materials and techniques. London.

Berger R. 1992. ${ }^{14} \mathrm{C}$ dating mortar in Ireland. Radiocarbon 34(3):880-9.

Borbein AH. 2000. Formanalyse. In: Hölscher T, Zanker P, editors. Klassische Archäologie. Eine Einführung. Berlin. p 109-28.

Canaan T. 1932. The Palestinian Arab house: its architecture. The Journal of the Palestine Oriental Society 12: 223-47.

Dalman G. 1942. Arbeit und Sitte in Palästina, Bd. 7, Das Haus, Hühnerzucht, Taubenzucht, Bienenzucht. Gütersloh.

Deckers JG. 1992. Wie genau ist eine Katakombe zu datieren? Das Beispiel SS. Marcellino e Pietro, in Memoria Sanctorum Venerantes. Miscellanea in onore di Mons. Victor Saxer, Studi di Antichità Cristiana 48: 217-38.

DeLaine J. 1997. The Baths of Caracalla. Porthsmouth.

Dix B. 1982. The Manufacture of lime and its uses in the western Roman provinces. Oxford Journal of Archaeology 1(3):331-45.

Fasola UM. 1976. Le due catacombe ebraiche di Villa Torlonia. Rivista di Archeologia Cristiana 52: 7-62.

Février P-A. 1989. À propos de la date des peintures des catacombes romaines. Rivista di Archeologia Cristiana 65:105-33.

Guyon J. 1994. Peut-on vraiment dater une catacombe? Retour sur le cimetière "Aux deux Lauriers," ou catacombe des saints Marcellin-et-Pierre, sur la via Labicana à Rome. Boreas 17:89-103.

Jackson DA. 1973. A Roman lime kiln at Weekley, Northants. Britannia 4:128-40.

Lanciani R. 1967. The destruction of ancient Rome. New York.
Lanciani R. 1975. Storia degli scavi di Roma e notizie intorno le collezioni romane di antichità. Vol. I, Bologna.

Lavergne D, Suméra F. 2000. La fabrication de la chaux: une activité pérenne ou occasionnelle pendant l'Antiquité gallo-romaine? Premiers éléments de réponse, in Pétrequin P. et al., eds, Arts dufeu et productions artisanales. XXe rencontres internationales d'archéologie et d'histoire d'Antibes, Antibes. p 453-72.

Lega C. 1999. Schola: Calcarienses. In: Steinby M, editor. Lexicon topographicum urbis Romae. Volume 4. Rome. p 243-4.

Martin R. 1965. Manuel d'architecture grecque. Volume 1. Matériaux et techniques. Paris.

Michalowski K. 1962. Les fouilles polonaises à Tell Atrib (1957-1959). Annales du Service des Antiquités de l'Égypte 57:49-66.

Noy D. 1995. Jewish inscriptions of Western Europe. Volume 2. Western Europe. Cambridge.

Noy D. 1998. Where were the Jews of the Diaspora buried? In: Goodman, MD, editor. Jews in a Graeco-Roman World. Oxford. p 75-89.

Osborne J. 1985. The Roman catacombs in the Middle Ages. Papers of the British School at Rome 53:278328.

Poblome J. et al. 2000. An early Byzantine tile and lime kiln in the territory of Sagalassos. In: Waelkens M, Loots L, editors. Sagalassos V: report on the survey and excavation campaigns of 1996 and 1997. Leuven. p 669-83.

Rutgers LV. 1995. The Jews in late ancient Rome. evidence of cultural interaction in the Roman Diaspora. Leiden.

Rutgers LV. 1998. Dating the Jewish catacombs of ancient Rome. In: The hidden heritage of Diaspora Ju- 
daism. Leuven. p 45-71.

Rutgers LV. 2000. Subterranean Rome. in search of the roots of Christianity in the catacombs of the Eternal City. Leuven.

Rutgers LV. Forthcoming. Final report on the Villa Torlonia catacomb project. Leuven.

Solin H. 1983. Juden und Syrer im westlichen Teil der römischen Welt. Aufstieg und Niedergang der römischen Welt 29.2:587-789.

Sölter W. 1970. Römische Kalkbrenner im Rheinland. Düsseldorf.

Spycher HP et al. 1981. Der römerzeitliche Kalkbrennofen von Vuippens/La Palaz (Kt. Freiburg, Schwiez). Jahrbuch des Römisch-Germanischen Zentralmuseums Mainz 28:171-96.

Stuiver M, Reimer PJ. 1993. Extended ${ }^{14} \mathrm{C}$ database and revised Calib $3.0{ }^{14} \mathrm{C}$ age calibration program, Radiocarbon 35(1):215-30 (Calib version 4.3 was used here).

Uscatescu A, Martín-Bueno M. 1997. The Macellum of Gerasa (Jerash, Jordan): from a market place to an industrial area. Bulletin of the American Schools of Oriental Research 307:67-88.

van der Borg K, Alderliesten CA, de Jong AFM, van der Brink A, de Haas AP, Kersemaekers HJH, Raaymakers JEMJ. 1997. Precision and mass fractionation in the ${ }^{14} \mathrm{C}$ analysis with AMS. Nuclear Instruments and Methods in Physical Research B123:97-101.

Viaene W et al. 1997. An archaeometric study of mortars used at Sagalassos. In: Waelkens M, Poblome J, editors. Sagalassos IV: report on the survey and excavation campaigns of 1994 and 1995. Leuven. p 405-21. 